\title{
Preface: Understanding dynamics and current developments of climate extremes in the Mediterranean region
}

\author{
R. F. Garcia-Herrera ${ }^{1}$, P. Lionello ${ }^{2,3}$, and U. Ulbrich $^{4}$ \\ ${ }^{1}$ Department of Physics of the Earth, Astronomy and Astrophysics, Complutense University of Madrid, Madrid, Spain \\ ${ }^{2}$ Department of Biological and Environmental Sciences and Technologies (DISTEBA), University of Salento, Lecce, Italy \\ ${ }^{3} \mathrm{CMCC}$, EuroMediterranean Center on Climate Change, Lecce, Italy \\ ${ }^{4}$ Institut für Meteorologie, Freie Universität Berlin, Berlin, Germany
}

Correspondence to: P. Lionello (piero.lionello@unisalento.it)

\begin{abstract}
There is an increasing interest of scientists on climate extremes. A progressively larger number of papers dealing with climate issues have been produced in the past $15 \mathrm{yr}$, and those dealing with extremes have increased at an even faster pace. The number of papers on extremes in the Mediterranean follows this overall trend and confirms how extremes are perceived to be important by the scientific community and by society. This special issue (which is mainly related to activities of the MedCLIVAR (Mediterranean CLImate VARiability and Predictability) and CIRCE (Climate Change and Impact Research: the Mediterranean Environment) projects), contains thirteen papers that are representative of current research on extremes in the Mediterranean region. Five have precipitation as its main target, four temperature (one paper addresses both variables), and two droughts; the remaining papers consider sea level, winds and impacts on society. Results are quite clear concerning climate evolution toward progressively hotter temperature extremes, but more controversial for precipitation, though in the published literature there are indications for a future increasing intensity of hydrological extremes (intense precipitation events and droughts). Scenario simulations suggest an attenuation of extreme storms, winds, waves and surges, but more results are requested for confirming this future change.
\end{abstract}

\section{Introduction}

The purpose of this special issue is to publish a collection of new research contributions addressing description and understanding of climate extremes in the Mediterranean region and of their evolution. It is meant to provide new and relevant information on a region that is critically affected by a wide range of extreme phenomena, such as extreme temperature and heat waves, extreme precipitation and flash floods, droughts, storm surges, etc. (e.g. Lionello et al., 2012b). To a large extent this special issue is based on studies carried out within the CIRCE FP6-EU project and the MedCLIVAR network. The CIRCE project (Climate Change and Impact Research: the Mediterranean Environment, http://www.circeproject.eu/) was designed to predict and quantify the physical impacts of climate change in the Mediterranean, including extremes. In particular its sixth work package (named "Extreme Events") was devoted to understand the current space-time distribution of extreme events over the Mediterranean region and how it could change in the 21 st century. Results are included in part 1 of Regional Assessment of Climate Change in the Mediterranean (Navarra and Tubiana, 2013), which deals with analyses of the physical aspects of climate change in the Mediterranean region. MedCLIVAR (Mediterranean CLImate VARiability and Predictability) operates as a scientific network, which is endorsed by CLIVAR and has been supported by the European Science Foundation for the period 2006-2011. This network (http://www.medclivar.eu) provides opportunities to discuss and disseminate scientific progress between different disciplines contributing to understanding the climate of the Mediterranean region and its evolution (Lionello et al., 2012a). The outcomes of this network have been published in two books (Lionello et al., 2006a; Lionello, 2012a). Extreme events are considered a very important topic within MedCLIVAR, and the second book devotes two chapters (Ulbrich et al., 2012; Xoplaki et al., 2012) specifically to them. These two projects are examples suggesting that extremes are an increasingly important topic and that they are perceived to be particularly relevant in the Mediterranean region. 


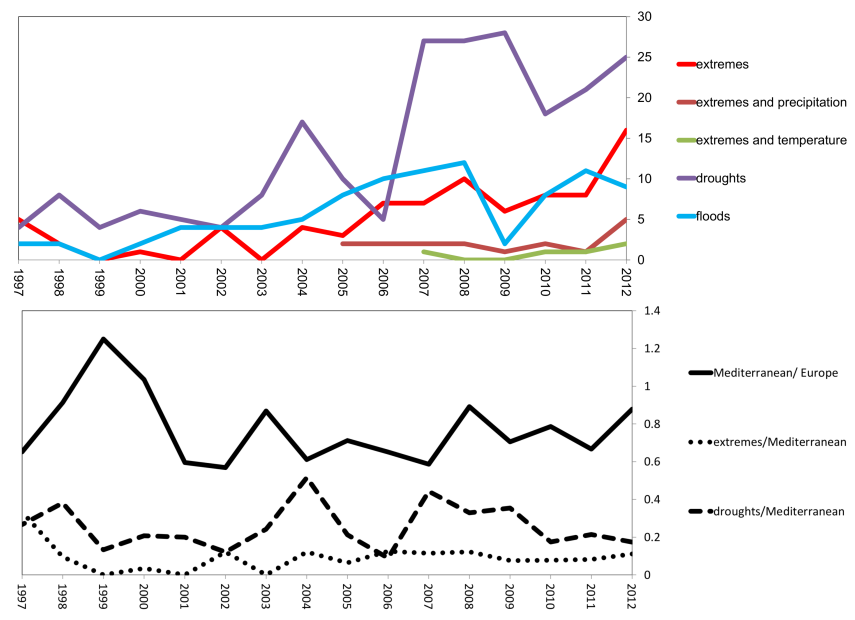

Fig. 1. Top panel: number of papers published each year in international journals whose title contains, in addition to the word "Mediterranean", either the words "floods" (light blue line), "drought" (violet line), "extremes" (red line), "extremes" and "precipitation" (brown line), or "extremes" and "temperature" (green line). Bottom panel: ratio between number of papers published each year in international journals whose title contains selected words: "Climate" and "Mediterranean" versus "Climate" and "Europe" or "European" (continuous line), "extremes" versus "Climate" and "Mediterranean" (dotted line), "drought" versus "climate" and "Mediterranean" (dashed line). Source: SCOPUS, http://www.scopus.com/.

Indeed, extremes are the object of an increasingly large number of scientific articles in climate and meteorological studies. Figure 1 shows (on the basis of the SCOPUS database) that the number of published articles containing in their title the words "Mediterranean" and "extreme(s)" has been, apart from obvious fluctuations, increasing and peaked at 16 articles in 2012. Figure 1 also shows that a substantial fraction has focused on precipitation extremes, much larger than on temperature extremes. The importance of the hydrological cycle is further emphasized considering the number of papers containing the words "drought(s)" and "flood(s)". Note that, in particular for "drought" papers, this number includes studies considering impacts of drought on other environmental and societal variables and the number of papers containing the word "drought(s)" is even larger than those containing the word "extreme(s)", which in turn is comparable to those with the word "flood(s)". This clearly shows the large perceived relevance of droughts and, to a lesser extent, of floods in the Mediterranean environment. It is however clear that in all these examples the number of published papers is now substantially larger than $10-15 \mathrm{yr}$ ago.

However, such an increase is not specific to the papers dealing with extremes and the Mediterranean region and Fig. 1 shows also that the number of papers dealing with Mediterranean climate with respect to those dealing with European climate has no clear trend. In fact, in general the number of published scientific papers has increased significantly in the last $15 \mathrm{yr}$. As an example the number of published papers mentioning the word "climate" in the title is about 4.2 times larger in the $5 \mathrm{yr}$ period 2008-2012 than in 1997-2001. The papers mentioning the word "drought" have increased comparably, but slightly more (4.6 times). However, those mentioning "climate" and "extremes" have increased 7 times and those mentioning extremes and Mediterranean 9 times. These records are meant to show the amount of studies that specifically focused on extremes as they mentioned them explicitly in the title. The number of studies which, to a different extent, include the extremes within their scope and address related issues would be much larger and it is difficult to quantify. However, on this partial basis, one can conclude that the number of papers focused on climate issues has increased remarkably in the last $15 \mathrm{yr}$. The fraction of papers focused on the Mediterranean region has comparably increased, but the number of paper dealing with extremes has increased faster.

Within this special issue, out of 13 papers five have precipitation as a main target, four temperature (one paper addresses both variables), and two droughts. The remaining papers consider sea level, winds and impacts on society. Consequently, also in this special issue, as in the general scientific literature, extremes of the hydrological cycle are more frequent than others in recent studies considering the Mediterranean climate and environment.

\section{Highlights of the special issue content}

This section contains highlights of the various contributions that are published in this special issue. In the call, contributions addressing one or more of the following aspects, which the editors considered most relevant for understanding extremes, where solicited:

- understanding the dynamics leading to extreme events in the Mediterranean,

- description of structural and/or statistical properties of Mediterranean extremes,

- links to large-scale climate patterns and teleconnections,

- present and recent (20th century) trends,

- reconstruction of extremes in the historical past,

- characterization of extremes at sub-regional scale, and

- extremes in future climate scenarios.

To some extent all these topics have been considered, except for reconstruction of extremes in the historical past. 


\subsection{Precipitation extremes}

Studies have considered the characterization of precipitation extremes (Toreti et al., 2010), the atmospheric dynamics responsible for their inter-annual variability (Gaetani et al., 2011), analysis of climate change at sub-regional scale (Iberia, OrtizBeviá et al., 2011), development of statistical methods for their correct estimate (Quintana-Seguí et al., 2011), identification of moisture sources (Drummond et al., 2011) and analysis of present-day climate in the wettest part of the Mediterranean region (Ducić et al., 2012).

Toreti et al. (2010) have analyzed daily precipitation extremes for the extended winter season (October-March) at 20 Mediterranean coastal sites covering the period 19502006. Precipitation extremes (identified from an exceedance of thresholds larger than the 90th percentile) give an important contribution to seasonal totals (approximately $60 \%$ for all series). In the 20 considered stations, $50 \mathrm{yr}$ return levels lay in the range $264 \mathrm{~mm}$ (Genoa) to $82 \mathrm{~mm}$ (Rome). Six series (from stations located in France, Italy, Greece, and Cyprus) show a significant negative trend in extreme event occurrence. In the western and northern Mediterranean, the anomalous surface to mid-tropospheric flow during extreme precipitation events is connected with enhanced moisture transport from the Atlantic (Trigo et al., 2006; Pinto et al., 2013). For the eastern Mediterranean extreme precipitation events are associated with a mid-tropospheric through, which extends from the north over the eastern Mediterranean (EM), and a low atmospheric pressure system over this part of the basin. This EM situation favors warm air advection connected with anomalous ascent motions and an increase of the low- to mid-tropospheric moisture content (Eshel and Farrell, 2000; Ziv et al., 2010).

The role of jet streams is extensively discussed by Gaetani et al. (2011). Two jet streams in the Euro-Atlantic region affect the rainfall distribution in the Mediterranean region during the rainy season (September-May): the Atlantic jet, which reaches Europe after crossing the Atlantic ocean, and the North African jet, which flows above the coast of North Africa. The rainfall distribution downstream to these jets is strongly influenced by their relative positions. Specifically, in fall, rainfall is abundant in the western Mediterranean basin (WM), when the Atlantic jet is relatively strong and its direction has a small northward tilt, and the African jet is in its easternmost position. In winter, rainfall is abundant in the eastern Mediterranean basin (EM) when the Atlantic jet reaches the Scandinavian Peninsula and the African jet is in its westernmost position. In spring, when the two jets weaken, rainfall is abundant in the Alpine region and in the Balkans if the Atlantic jet retreats over the ocean while the African jet stays in its winter position.

Drummond et al. (2011) have investigated variation of moisture sources related to drier and wetter conditions in the different areas that surround the Mediterranean Basin. Authors have found that the North Atlantic is a main source of moisture for the Iberian Peninsula, for France and for central North Africa. The Mediterranean Sea is the predominant source for eastern North Africa, the Italian and Balkan Peninsulas, while local sources provide moisture for the eastern Mediterranean and western North Africa.

Ducić et al. (2012) have analyzed indices of extreme precipitation in Krivošije, Montenegro, and in the wettest Mediterranean region, from the period 1951-2007. Their results suggest that northerly, easterly and southerly circulation types are more frequent for wet and very wet days. In particular weather types with cyclonic condition over central Europe show a large proportion of wet and very wet days. The Genoa cyclogenesis and the orographic influence over a small area are the main causes for the high precipitation amounts recorded in the Krivošije region.

OrtizBeviá et al. (2011) have computed possible changes in the probability of occurrence of winter (DJFM) extremes of minimum temperature and precipitation in Iberia by projecting the changes in the probability of occurrence of the North Atlantic scale winter atmospheric regimes that are associated with them. Results are based on a set of three simulations performed at MeteoFrance with the Arpege model (Dequé et al., 1994) and suggest a future with less precipitation (and low temperature) extreme events in winter in the westerly central part of the Iberian peninsula.

Quintana-Seguí et al. (2011) compared three different statistical downscaling methods (the anomaly method, quantile mapping and a weather typing) for computing extremes of precipitation and of river flow. Though these methods produce qualitatively similar future scenarios of the extremes of river flow, there are still significant differences between them for individual gauging stations. According to these scenarios, it is expected that in the middle of the 21 st century (2035-2064) the monthly low river flows will have diminished almost everywhere in the French Mediterranean region by as much as $20 \%$, and high flows will have increased (the $10 \mathrm{yr}$ return floods are expected to carry $100 \%$ more water than at the end of the 20th century). It is, however, not clear to which extend this study can account for the increase moisture content of the Mediterranean atmosphere in a future warmer climate and its effect on the intensity of precipitation.

\subsection{Temperature extremes}

The studies in this issue reinforces the picture of a future progressively warmer Mediterranean with extremes consistently warmer than presently.

Efthymiadis et al. (2011) have analyzed temperature extremes in two recently available daily gridded data sets (ERA-40, Uppala et al., 2005; EOBS, Haylock et al., 2008) and show a strong west-east contrast, with the rate of increase in the west in line with global trends, while in the east a cooling is observed in winter, with reversal in the last two decades. The intensification of the increasing trend in warm/hot extremes (daily maximum and minimum 
temperature, $T_{\max }$ and $T_{\min }$, respectively) is evident over the last $15-20 \mathrm{yr}$ over the whole region. This study has confirmed a number of the relationships between Mediterranean temperature extremes and large-scale circulation previously identified or proposed (e.g. Ulbrich et al., 2012). It has further shown the complexity of these relationships and that it is unlikely that atmospheric circulation variability alone can explain the observed trends in hot temperature extremes and their amplification in the last decade. The influence of other factors such as warming sea surface and soil moisture feedback are likely important.

Hertig et al. (2010) have analyzed ongoing trends (19611990) and future (end of 21st century) of extreme temperatures. The west-east contrast is confirmed. Increases (more than $2{ }^{\circ} \mathrm{C}$ at some station for $T_{\max } 95$ th percentile) can be identified in the western Mediterranean area but not in the eastern Mediterranean. During the 21st century, statistical downscaling techniques show mainly positive trends of both extreme indices $\left(T_{\max }\right.$ 95th percentile and $T_{\min }$ 5th percentile), but considerable uncertainties are associated with the choice of different predictors or predictor combinations, as the downscaling results are hampered by widespread nonstationarities in the predictor-extreme-temperature relationships. In general, increases for extreme minimum temperatures in winter show more consistency than the signal for maximum temperatures in summer. This study indicates that the intra-annual extreme temperature range will decrease in large parts of the Mediterranean area, in agreement with the overall global tendency, but in contrast to the opposite increasing trend previously found (Tebaldi et al., 2006). Furthermore, the results give strong indications that changes in temperature extremes do not follow a simple shift of the whole temperature distribution to higher values.

At smaller, sub-regional scale El Kenawi et al. (2011) have investigated the spatial and temporal characteristics of extreme temperature events in north-eastern Spain for the period 1960-2006. The observed changes are more prevalent in hot extremes than in cold extremes and they can largely be linked to the increase found in the mean maximum temperature during the last few decades. A significant increase in warm nights, warm days, tropical nights and the annual $T_{\max }$ was detected in the $47 \mathrm{yr}$ period.

Considering future minimum temperature for the A1B scenario and greenhouse gases concentration at the 2100 levels, OrtizBeviá et al. (2011) have computed possible changes in the probability of occurrence of winter (DJFM) extremes and have shown milder minimum temperature extreme events in the westerly central part of the Iberian Peninsula.

\subsection{Winds and sea level}

In general, the systematic detection of hazardous systems, based on cyclone characteristics, is complicated because no linear relationship exists between the intensity of cyclones and their impacts (e.g. Lionello et al., 2006b). To overcome this problem, Nissen et al. (2010) have developed an impactbased approach that combines a cyclone detection technique with a wind track detection algorithm and have thus produced a climatology of cyclones with a focus on their relation to wind storm tracks in the Mediterranean region. Areas with high wind activity are typically located south of the Golf of Genoa, south of Cyprus, south-east of Sicily and west of the Iberian Peninsula. About $42 \%$ of the windstorms are caused by cyclones originating inside the Mediterranean region (19\% from the eastern and $23 \%$ for the western Mediterranean region), while the remaining $58 \%$ originate further away, mostly over the Atlantic. Moreover, $31 \%$ of the cyclones causing windstorms in the Mediterranean never cross the region, but pass along more northerly tracks. The strongest connection with storm tracks exists for the NAO (North Atlantic Oscillation) and the EAWR (eastern Atlantic-western Russia) patterns, which are both associated with an increase in the number of strong wind events in the eastern Mediterranean region during their positive phase. On the other hand, the storm number decreases over the western and central Mediterranean region for the positive phase of the NAO and of the EAWR pattern, respectively. The positive phase of the Scandinavian pattern is associated with a decrease in the number of winter windstorms over most of the Mediterranean region. In line with the results of other authors (e.g. Trigo et al., 2008; Trigo, 2005; Maheras et al., 2001), this study finds a significant decrease of the number of cyclones during the second half of the 20th century over the western Mediterranean basin and over the Black Sea.

Tsimplis and Shaw (2010) have explored the spatial and temporal variability of sea level extremes in the Mediterranean Sea and the Atlantic coasts of the Iberian Peninsula on seasonal timescales. The Atlantic stations show larger extreme values than the Mediterranean Sea primarily due to the tidal signal. In the western Mediterranean the observed extreme values are less than $50 \mathrm{~cm}$, except near the Strait of Gibraltar and in the northern Adriatic Sea. Direct atmospheric forcing contributes significantly to sea level extremes. Maximum sea level values due to atmospheric forcing reach in some stations $45 \mathrm{~cm}$ during the winter, and are between 10 and $20 \mathrm{~cm}$ in the summer. Past changes in extremes have been dominated by changes in the mean sea level. Though trends in the $99.9 \%$ percentiles and correlation with NAO are present in several areas, most of them are removed when the $50 \%$ percentile is subtracted indicating that changes in the extremes are in line with mean sea level change.

\subsection{Droughts and their socio-economic impact}

Sousal et al. (2011) have analyzed the spatial and temporal evolution of drought conditions in the Mediterranean region during the 20th century using the self-calibrated Palmer Drought Severity Index (scPDSI) and found a clear trend towards drier conditions in most western and central 


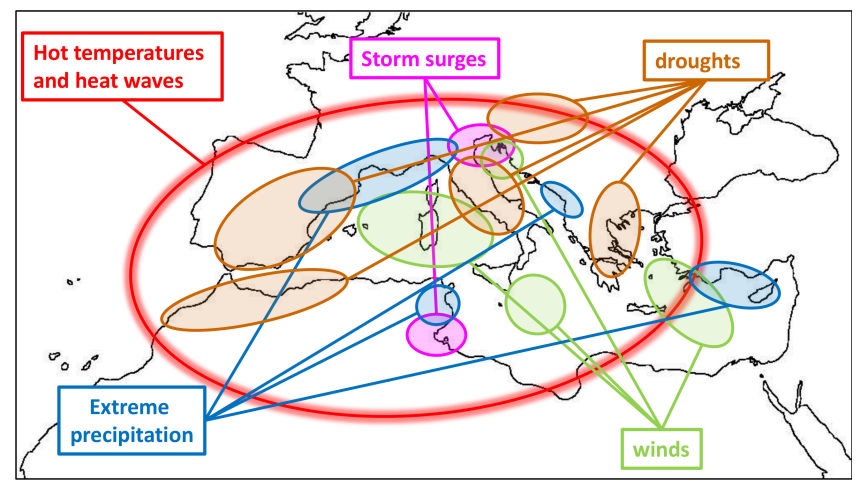

Fig. 2. Simplified illustration showing areas where critical issues have been specifically documented, because of intensity of hazards, of observed past trends or expected future changes.

Mediterranean regions, with the exceptions of north-western Iberia and most of Turkey, which instead reveal an increase of moisture availability. A significant decline of absolute (positive and negative) extreme values of scPDSI in central areas (Italy and Balkans) has been found. The main driver of scPDSI in western and central Mediterranean areas is the winter NAO pattern, which is relevant also during the following spring and summer seasons. The second most important mode corresponds to the Scandinavian pattern which is significantly associated with the scPDSI between winter and summer over central Mediterranean. The study confirms the trend towards drier conditions over a large fraction of the western and central Mediterranean region (e.g. Trigo et al., 2006).

Quiroga et al. (2011) have analyzed the economic value of information on drought events management taking into account the risk aversion of water managers (the more risk aversion, the less the value of the climate information). Considering the rice production in the Ebro River basin, the two explored alternatives are (a) to reduce water allocation for irrigation in order to eliminate the risk of water scarcity, and (b) to maintain water allocation and accept a reduction of water supply reliability, leaving farmers exposed to drought events. These two alternatives offer different risk levels for crop production and farmers' incomes. The value of providing improved information and projections of climate change and extreme events to help managers to choose between these two alternatives is demonstrated.

\section{Discussion}

This special issue has collected contributions on extreme precipitation, droughts, hot temperatures, and storms. It provides a representative sampling of the main hazards affecting the Mediterranean region. Figure 2 is meant to show some areas where critical issues have been specifically documented, because of intensity of hazards, of observed past trends or expected future changes. It is a simplified illustration that does not aim at summarizing the complexity of local situations and at containing all relevant hazards.

Extreme precipitation in the Mediterranean region is extensively investigated in the scientific literature (Ulbrich et al., 2012). Stations show very large daily precipitation along the north-west Mediterranean coast (Toreti et al., 2010; Reale and Lionello, 2013). It is difficult to identify a homogeneous tendency of extreme precipitation events in the past five or six decades across the various studies, though there are some indications (confirmed by this special issue) that extreme precipitations are becoming more intense (see Ulbrich et al. 2012 for a review) and this tendency would continue for the next decades (Planton et al., 2012; Gualdi et al., 2013), in spite of a progressively drier Mediterranean environment in the future. In order to increase the robustness of conclusions in terms of the trends of extremes, the number, length and quality of time series available for analysis must be increased. An initiative leading to a public archive of in situ daily precipitation time series would be very important for future research on this issue. Considering future evolution of precipitation extremes, climate models are improving, especially in terms of the required higher spatial resolution and of the intensity of the events. Studies analyzing large-scale processes and atmospheric circulation features leading to extreme precipitation, such as OrtizBeviá et al. (2011) and Gaetani et al. (2012) in this special issue, are very important to complement and interpret model results (see Xoplaki et al., 2012, for a review).

Droughts, which are in general associated with absence of precipitation, are the opposite environmental condition and a major hazard as well. Conditions leading to drought are extensively discussed in Xoplaki et al. (2012). The paper by Sousa et al. (2011) provides clear evidence that large areas of the Mediterranean region have become increasingly dry during the 20th century. Increasingly warm conditions and decrease of mean precipitation are expected to continue this trend during the 21 st century. However, a precise evaluation of the future evolution is not available at Mediterranean scale, and though the Mediterranean is among the regions where a climate change signal is most evident, there are problems with a robust assessment of future trends (Orlowsky and Seneviratne, 2013), which need to be overcome.

Results are much more certain on extreme temperatures in term of association with large-scale patterns, past and future evolution. An example is the role of NAO on extreme hot temperatures in the present climate: extreme $T_{\max }$ are associated with negative phase of NAO over most of the Mediterranean region, but in the north-western corner and the Middle East where they are associated with positive NAO (Yiou and Nogaj, 2004). A general warming, affecting both temperature minima and maxima, is a well-recognized feature of the evolution of climate in the Mediterranean region both in the recent past (see Efthymiadis et al., 2011; Ulbrich et al., 2012, for a review) and in the 21st century (Planton et al., 2012, for 
a review). In general, the results of statistical methods (Hertig et al., 2010) and of "grand ensemble" of climate simulations provided by the climateprediction.net (Planton et al. 2012) project (CPDN) agrees that changes in temperature extremes do not follow a simple shift of the whole temperature distribution to higher values, and both broadening and nonsymmetric changes in the frequency distributions of Mediterranean temperatures will occur in the future, with important effect on extremes. It is however difficult to provide a robust geographical distribution of changes. Actually, areas where warmer temperature extremes are expected from an extrapolation of trends in the recent past (according to Hertig et al., 2010) are different from those where the largest mean temperature increase is expected in global climate models (e.g. Giorgi and Lionello, 2008). This is the reason why there is no sub-regional characterization for extreme temperatures distribution in Fig. 2. However recent past and future increase appear to be more relevant for the western than for the eastern Mediterranean region.

A general decrease in the frequency of cyclones associated with extreme winds and no significant change in the intensity of the most extreme wind storms has been found (see Nissen et al., 2010; Ulbrich et al., 2012, for reviews). The northern Adriatic Sea is the area most frequently considered for sea level extremes produced by storms. It is the area where both storm surges and astronomical tide have the largest amplitude in the Mediterranean basin (e.g. Tsimplis et al., 1995; Marcos et al., 2009). Further along its flat and densely populated coast there are large economic and cultural values potentially at risk. This combination of factors explains the relevance of this area in the scientific literature (see Lionello, 2012b for a summary of recent findings). The second critical area considering the level of the hazards is the Gulf of Gabés, on which, however, there are fewer published papers. In any case, studies so far have not suggested a significant change of sea level extremes in the recent past and in the 21st century, except for the effect of mean sea level increase (see Tsimplis and Shaw, 2010; Planton et al., 2012, for reviews).

This short discussion is focused on extreme hazards and their evolution, which are not to be confused with extremes leading to actual large risks, which depend also on exposure and vulnerability and need a specific investigation accounting for these two factors. Figure 2 shows the location of the hazards discussed in the papers that are mentioned in this editorial (see list of references) and it is meant to provide a simplified overview of the hazards most frequently occurring in the Mediterranean region.

Acknowledgements. The proposal for this special issue has been initiated within the CIRCE (EU-fp6 project, contract number 036961) and supported by the MedCLIVAR network (www.medclivar.eu).

\section{References}

Dequé, J., Dreveton, C., Braun, A., and Carriolle, D.: The Arpege/IFS atmosphere model: A contribution to the French community climate modelling, Clim. Dynam., 10, 249-266, doi:10.1007/BF00208992, 1994.

Drumond, A., Nieto, R., Hernandez, E., and Gimeno, L.: A Lagrangian analysis of the variation in moisture sources related to drier and wetter conditions in regions around the Mediterranean Basin, Nat. Hazards Earth Syst. Sci., 11, 2307-2320, doi:10.5194/nhess-11-2307-2011, 2011.

Ducić, V., Luković, J., Burić, D., Stanojević, G., and Mustafić, S.: Precipitation extremes in the wettest Mediterranean region (Krivošije) and associated atmospheric circulation types, Nat. Hazards Earth Syst. Sci., 12, 687-697, doi:10.5194/nhess-12687-2012, 2012.

Efthymiadis, D., Goodess, C. M., and Jones, P. D.: Trends in Mediterranean gridded temperature extremes and large-scale circulation influences, Nat. Hazards Earth Syst. Sci., 11, 21992214, doi:10.5194/nhess-11-2199-2011, 2011.

El Kenawy, A., López-Moreno, J. I., and Vicente-Serrano, S. M.: Recent trends in daily temperature extremes over northeastern Spain (1960-2006), Nat. Hazards Earth Syst. Sci., 11, 25832603, doi:10.5194/nhess-11-2583-2011, 2011.

Eshel, G. and Farrell, B. F.: Mechanisms of Eastern Mediterranean rainfall variability, J. Climate, 57, 3219-3232, 2000.

Gaetani, M., Baldi, M., Dalu, G. A., and Maracchi, G.: Jetstream and rainfall distribution in the Mediterranean region, Nat. Hazards Earth Syst. Sci., 11, 2469-2481, doi:10.5194/nhess-112469-2011, 2011.

Gualdi, S., Somot, S., May, W., Castellari, S., Déqué, M., Adani, M., Artale, V., Bellucci, A., Breitgand, J. S., Carillo, A., Cornes, R., Dell'Aquila, A., Dubois, C., Efthymiadis, D., Elizalde, A., Gimeno, L.,Goodess, C. M., Harzallah, A., Krichak, S. O., Kuglitsch, F. G., Leckebusch, G. C., L’Hévéder, B., Li, L., Lionello, P., Luterbacher, J., Mariotti, A., Navarra, A., Nieto, R., Nissen, K. M., Oddo, P., Ruti, P., Sanna, A. Sannino, G., Scoccimarro, E., Sevault, F., Struglia, M. V., Toreti, A., Ulbrich, U., and Xoplaki, E.: Future climate projections, in: Regional Assessment of Climate Change in the Mediterranean, Advances in Global Change Research, edited by: Navarra, A. and Tubiana, L., Springer Netherlands, 50, 53-118, ISBN: 978-94-007-57806 (Print) 978-94-007-5781-3 (Online), 2013.

Haylock, M. R., Hofstra, N., Klein Tank, A. M. G., Klok, E. J., Jones, P. D., and New, M.: A European daily high resolution gridded data set of surface temperature and precipitation for 1950-2006, J. Geophys. Res., 113, D20119, doi:10.1029/2008JD010201, 2008.

Hertig, E., Seubert, S., and Jacobeit, J.: Temperature extremes in the Mediterranean area: trends in the past and assessments for the future, Nat. Hazards Earth Syst. Sci., 10, 2039-2050, doi:10.5194/nhess-10-2039-2010, 2010.

Lionello, P. (Ed.): The climate of the Mediterranean region, From the past to the future, Elsevier, ISBN: 9780124160422496 pp., 2012 a.

Lionello, P.: The climate of the Venetian and North Adriatic region: Variability, trends and future change, Phys. Chem. Earth, 40-41, $1-8,2012$ b. 
Lionello, P., Malanotte-Rizzoli, P., and Boscolo, R.(Eds): Mediterranean Climate Variability Elsevier, Amsterdam, NETHERLANDS, ISBN: 0-444-52170-4, 438 pp., 2006a.

Lionello, P., Bhend, J., Buzzi, A., Della-Marta, P. M., Krichak, S. O., Jansà, A., Maheras, P., Sanna, A., Trigo, I. F., and Trigo, R.: Cyclones in the Mediterranean region: climatology and effects on the environment, in: Mediterranean Climate Variability, edited by: Lionello, P., MalanotteRizzoli, P., and Boscolo, R., Developments in Earth \& Environmental Sciences 4, Elsevier, 325-372, $2006 b$.

Lionello, P., Gacic, M., Gomis, D., Garcia-Herrera, R., Giorgi, F., Planton, S., Trigo, R., Theocharis, A., Tsimplis, M. N., Ulbrich, U., and Xoplaki, E.: Program focuses on climate of the Mediterranean region Eos Trans. AGU, 93, 105-106, 2012a.

Lionello, P., Abrantes, F., Congedi, L, Dulac, F., Gacic, M., Gomis, D., Goodess, C., Hoff, H., Kutiel, H., Luterbacher, J., Planton, S., Reale, M., Schröder, K., Struglia, M. V., Toreti, A., Tsimplis, M. N., Ulbrich, U., and Xoplaki, E.: Introduction: Mediterranean Climate: Background Information in: The Climate of the Mediterranean Region, From the Past to the Future, edited by: Lionello, P., Amsterdam, Elsevier (NETHERLANDS), xxxv-xc, ISBN:9780124160422, 2012b.

Lionello, P., Cavaleri, L., Nissen, K. M., Pino, C., Raicich, F., Ulbrich, U.: Severe marine storms in the Northern Adriatic: Characteristics and trends, Phys. Chem. Earth, 40-41, 93-105, doi:10.1016/j.pce.2010.10.002, 2012c.

Maheras, P., Flocas, H., Patrikas, I., and Anagnostopoulou, C.: A 40 year objective climatology of surface cyclones in the Mediterranean region: spatial and temporal distribution, Int. J. Climatol., 21, 109-130, doi:10.1002/joc.599, 2001.

Marcos, M., Tsimplis, M. N., and Shaw, A. G. P.: Sea level extremes in Southern Europe, J. Geophys. Res., 114, C01007, doi:10.1029/2008JC004912, 2009.

Navarra, A., and Tubiana, L. (Eds): Regional Assessment of Climate Change in the Mediterranean. Volume 1: Air, Sea and Precipitation and Water in Advances in Global Change Research, 50, 338 pp., ISBN: 978-94-007-5780-6 (Print) ISBN 978-94-0075781-3 (Online), 2013.

Nissen, K. M., Leckebusch, G. C., Pinto, J. G., Renggli, D., U1brich, S., and Ulbrich, U.: Cyclones causing wind storms in the Mediterranean: characteristics, trends and links to largescale patterns, Nat. Hazards Earth Syst. Sci., 10, 1379-1391, doi:10.5194/nhess-10-1379-2010, 2010.

Orlowsky, B. and Seneviratne, S. I.: Elusive drought: uncertainty in observed trends and short- and long-term CMIP5 projections, Hydrol. Earth Syst. Sci., 17, 1765-1781, doi:10.5194/hess-171765-2013, 2013.

OrtizBeviá, M. J., SánchezGómez, E., and Alvarez-García, F. J.: North Atlantic atmospheric regimes and winter extremes in the Iberian peninsula, Nat. Hazards Earth Syst. Sci., 11, 971-980, doi:10.5194/nhess-11-971-2011, 2011.

Pinto, J. G., Ulbrich, S., Parodi, A., Rudari, R., Boni, G., and Ulbrich, U.: Identification and ranking of extraordinary rainfall events over Northwest Italy: The role of Atlantic moisture. J. Geophys. Res. Atmos., 118, 2085-2097, doi:10.1002/jgrd.50179, 2013.

Planton S., Lionello, P., Artale, V., Aznar, R., Carrillo, A., Colin, J., Congedi, L., Dubois, C., Elizalde, A., Gualdi, S., Hertig, E., Jacobeit, J., Jordà, G., Li, L., Mariotti, A., Piani, C., Ruti, P.,
Sanchez-Gomez, E., Sannino, G., Sevault, F., Somot, S., and Tsimplis, M. N.: The Climate of the Mediterranean Region in Future Climate, in: The Climate of the Mediterranean Region, From the Past to the Future, edited by: Lionello, P., Amsterdam: Elsevier (NETHERLANDS), Projections 449-502, 2012.

Quintana-Seguí, P., Habets, F., and Martin, E.: Comparison of past and future Mediterranean high and low extremes of precipitation and river flow projected using different statistical downscaling methods, Nat. Hazards Earth Syst. Sci., 11, 1411-1432, doi:10.5194/nhess-11-1411-2011, 2011.

Quiroga, S., Garrote, L., Iglesias, A., Fernández-Haddad, Z., Schlickenrieder, J., de Lama, B., Mosso, C., and Sánchez-Arcilla, A.: The economic value of drought information for water management under climate change: a case study in the Ebro basin, Nat. Hazards Earth Syst. Sci., 11, 643-657, doi:10.5194/nhess11-643-2011, 2011.

Reale, M. and Lionello, P.: Synoptic climatology of winter intense precipitation events along the Mediterranean coasts, Nat. Hazards Earth Syst. Sci., 13, 1707-1722, doi:10.5194/nhess-131707-2013, 2013.

Sousa, P. M., Trigo, R. M., Aizpurua, P., Nieto, R., Gimeno, L., and Garcia-Herrera, R.: Trends and extremes of drought indices throughout the 20th century in the Mediterranean, Nat. Hazards Earth Syst. Sci., 11, 33-51, doi:10.5194/nhess-11-33-2011, 2011.

Tebaldi, C., Hayhoe, K., Arblaster, J. M., and Meehl, G. A.: Going to the extremes. An intercomparison of model-simulated historical and future changes in extreme events, Climatic Change, 79, 185-211, 2006.

Toreti, A., Xoplaki, E., Maraun, D., Kuglitsch, F. G., Wanner, H., and Luterbacher, J.: Characterisation of extreme winter precipitation in Mediterranean coastal sites and associated anomalous atmospheric circulation patterns, Nat. Hazards Earth Syst. Sci., 10, 1037-1050, doi:10.5194/nhess-10-1037-2010, 2010.

Trigo, I. F.: Climatology and interannual variability of stormtracks in the Euro-Atlantic sector: a comparison between ERA40 and NCEP/NCAR reanalyses, Clim. Dynam., 26, 127-143, doi:10.1007/s00382-005-0065-9, 2005.

Trigo, R., Xoplaki, E., Zorita, E., Luterbacher, J., Krichak, S.O., Alpert, P., Jacobeit, J., Sáez, J., Fernández, J., GonzálezRouco, F., Garcia-Herrera, R., Rodo, X., Brunetti, M., Nanni, T., Maugeri, M., Trkes, M., Gimeno, L., Ribera, P., Brunet, M., Trigo, I. F., Crepon, M., and Mariotti, A.: Relations between variability in the Mediterranean region and mid-latitude variability, in: Mediterranean Climate Variability, edited by: Lionello, P., Malanotte-Rizzoli, P., and Boscolo, R., Amsterdam, Elsevier, 179-226, 2006.

Trigo, R. M., Valente, M. A., Trigo, I. F., Miranda, P., Ramos, A M., Paredes, D., and Garcia-Herrera, R.: The Impact of North Atlantic Wind and Cyclone Trends on European Precipitation and Significant Wave Height in the Atlantic, Ann. N.Y. Acad. Sci., 1146, 212-234, 2008

Tsimplis, M. N. and Shaw, A. G. P.: Seasonal sea level extremes in the Mediterranean Sea and at the Atlantic European coasts, Nat. Hazards Earth Syst. Sci., 10, 1457-1475, doi:10.5194/nhess-101457-2010, 2010

Tsimplis, M. N., Proctor, R., and Flather, R. A.: A two-dimensional tidal model for the Mediterranean Sea, J. Geophys. Res., 100, $16223-16239,1995$. 
Ulbrich, U., Lionello, P., Belušić, D., Jacobeit, J., Knippertz, P., Kuglitsch, F. G., Leckebusch, G. C., Luterbacher, J., Maugeri, M., Maheras, P., Nissen, K. M., Pavan, V., Pinto, J. G., Saaroni, H., Seubert, S., Toreti, A., Xoplaki, E., and Ziv, B.: Climate of the Mediterranean: Synoptic Patterns, Temperature, Precipitation, Winds, and Their Extremes in: The Climate of the Mediterranean Region, From the Past to the Future, edited by: Lionello, P., Amsterdam, Elsevier (NETHERLANDS), 301-346, ISBN:9780124160422, 2012.

Uppala, S. M., Kållberg, P. W., Simmons, A. J., Andrae, U., da Costa Bechtold, V., Fiorino, M., Gibson, J. K., Haseler, J., Hernandez, A., Kelly, G. A., Li, X., Onogi, K., Saarinen, S., Sokka, N., Allan, R. P., Andersson, E., Arpe, K., Balmaseda, M. A., Beljaars, A. C. M., van de Berg, L., Bidlot, J., Bormann, N., Caires, S., Chevallier, F., Dethof, A., Dragosavac, M., Fisher, M., Fuentes, M., Hagemann, S., Hólm, E., Hoskins, B. J., Isaksen, L., Janssen, P. A. E. M., Jenne, R., McNally, A. P., Mahfouf, J.-F., Morcrette, J.-J., Rayner, N. A., Saunders, R. W., Simon, P., Sterl, A., Trenberth, K. E., Untch, A., Vasiljevic, D., Viterbo, P., and Woollen, J.: The ERA-40 Reanalysis, Q. J. Roy. Meteor. Soc., 131, 2961-3012, doi:10.1256/qj.04.176, 2005.
Xoplaki, E., Trigo, R. M., García-Herrera, R., Barriopedro, D., D’Andrea, F., Gimeno, L., Gouveia, C., Hernandez, E., Kuglitsch, F. G., Mariotti, A., Nieto, R., Pinto, J. G., PozoVázquez, D., Saaroni, H., Toreti, A., Trigo, I. F., VicenteSerrano, S. M., Yiou, P., and Ziv, B.: Large-Scale Atmospheric Circulation Driving Extreme Climate Events in the Mediterranean and its Related Impacts, in: The Climate of the Mediterranean Region. From the Past to the Future, edited by: Lionello, P., Amsterdam, Elsevier (The Netherlands), 347-502, SBN:9780124160422, 2012.

Yiou, P. and Nogaj, M.: Extreme climatic events and weather regimes over the North Atlantic: when and where?, Geophys. Res. Lett., 31, L07202, doi:10.1029/2003GL019119, 2004.

Ziv, B., Saaroni, H., Romen, M., Heifetz, E., Harnik, N., and Baharad, A.: Analysis of conveyor belts in winter Mediterranean cyclones, Theor. Appl. Climatol., 99, 441-455, 2010. 